\title{
Men in Charge? Rethinking Authority in Muslim Legal Tradition
}

Ziba Mir-Hosseini, Mulki Al-Sharmani, and Jana Rumminger, eds. London: Oneworld Publications, 2014. 286 pages.

At a time when men's assumption of leadership roles through all-male events and publications is a popular phenomenon, Men in Charge?, a byproduct of a project by the women-led organization Musawah, could not have been published at a more opportune moment. Comprising a foreword by Zainah Anwar, Musawah's director, an introduction by the editors, and ten chapters from academics and activists of varied backgrounds, the book historicizes and problematizes the Islamic idea of qiwāmah (authority) and wilāyah (guardianship), among other legal patriarchal precepts. It successfully argues that the Islamic legal tradition with regards to gender roles rests on the false notion of male superiority.

Men in Charge? carries immeasurable value for scholars and students of Islam, religion, women's and gender studies, activists working toward gender-egalitarianism, and (Muslim) feminists seeking empowerment within a religious framework. It also speaks to reform leaders and lawmakers in Muslim states, who might better understand the fundamental assumptions upon which family laws operate and their disconnect from the reality that women and families face. The book's major success lies in covering several important layers of the myth of male authority, from the theoretical gaps in the notions of qiwāmah, wilāyah, and istikhlāf to a practical examination of the impact of these legal principles and proposals for new and creative approaches for feminists to apply in their vision of a gender-egalitarian Islam.

Men in Charge? can be divided into two sections: (1) a theoretical discussion of the problems raised through fiqh rulings on gender and proposes new ways through which Muslim feminists can approach those problems and (2) an analysis of the established ideals' practical impacts. Ziba Mir-Hosseini's discussion in the first chapter, "Muslim Legal Tradition and the Challenge of Gender Equality," effectively contextualizes the book's broader discussion: What Muslim scholars did in the early twentieth century to challenge the legal tradition's normative thought in an effort to move toward more democratic and egalitarian family systems.

According to the ideas of the scholars from the past and those from the more modern period, there appears to be an inconsistency between the two groups' understanding of "woman." This suggests that the idea of woman is 
reified, rather than clearly defined, by "Islam." Omaima Abou-Bakr, in "The Interpretive Legacy of Qiwāmah as an Exegetical Construct," shows this by tracing the evolving meaning of qawwamün in the exegetical tradition. She demonstrates that through multiple interpretive philosophies, the Qur'an's descriptive reference to men as qawwamun evolved historically into the normative prescriptive construction of qiyām (later qiwāmah). This concept thus gradually developed as a juristic model that shapes hierarchical gender relations in Muslim family dynamics.

Asma Lamrabet continues this evolutionary approach by discussing the evolution of three concepts from what was, she argues, originally Qur'anically intended to be spiritual conceptions to what later emerges as a patriarchal tool against women: "istikhlaf (equality in building human civilization), wilayah (shared responsibility of men and women), and qiwamah (management of public and private space by men and women)" (p. 66). She also highlights the role of politics in these terms' shifting definitions. Her argument that qiwāmah was never meant to be understood as an honor but as a responsibility that functions exclusively within a normative framework of conjugal relations, may be seen as a subtle reaffirmation of the traditional claim that the husbands' responsibility for their wives validates their authority over women. However, Lamrabet denies any direct link between responsibility and authority, arguing that existing links result from the patriarchal conceptual framework of traditional notions of marriage. The chapter is an excellent example of Muslim jurists' compromising Qur'anic principles in order to enforce patriarchy.

Ayesha Chaudhry and Sa'diyya Shaikh offer insightful strategies for feminists. In her "Producing Gender-Egalitarian Islamic Law: A Case Study of Guardianship (Wilāyah) in Prophetic Practice," Chaudhry writes how Muslim feminists and reformers can challenge forced marriages and increase women's agency in marriage and divorce. She suggests that viewing Prophet Muhammad as a complex figure - who, while a part of a patriarchal social milieu, made efforts to interrupt patriarchy and limit men's rights - would solidify the gender-egalitarian cause. Recognizing that her strategy may appear disingenuous and selective, Chaudhry reminds readers that selective approaches like this "have always appeared in Muslim writings, in the pre- and postcolonial periods" (p. 103).

Similarly, Shaikh suggests, in her "Islamic Law, Sufism, and Gender: Rethinking the Terms of the Debate," that a Sufi-oriented approach to evaluating gender relations in figh can extract a benevolent interpretation of the Shari'ah. Her analysis of Ibn Arabi's ontological framework based on the relationship 
between jamāl (beauty) and jalāl (majesty) as fundamental to Islam, as well as his religious constructions of "women," "men," and God-human relationships, are especially useful arguments for Muslim feminists. Further, her compelling discussion of Muslim religious anthropology, which "addresses question of what it means to be a human being from a religious perspective" (p. 106), provides new avenues for re-examining Muslims' relations with each other and with God.

Concentrating on the family codes in Morocco and the United Arab Emirates, Lynn Welchman's chapter functions as a transition into the practical and legal adaptations of wilāyah and qiwämah discussed in proceeding chapters. Welchman offers a brief history of the codification processes and the reforms of family laws in the Arab world under the aegis of larger political powers. Exploring issues of maintenance, obedience, divorce, and male guardianship over children, she also examines the Convention on the Elimination of all Forms of Discrimination against Women's (CEDAW) reports on women in the Arab world. The chapter also discusses the CEDAW committee's critical engagements with laws that, taking a man's qiwämah as a norm, secure the husband's status as the head of the family and the rights he enjoys in exchange.

The last three chapters examine the practical impact of ideas of wilayyah and qiwämah and their failure to speak to women's realities as well as to protect their rights. Marwa Sharafeldin investigates Egyptian activists' efforts to reform the current Personal Status Law (PSL), which has a detrimental effect on women and families. She explores the contentious relationship between the NGOs' proposals for reforms and the dominant Islamic jurisprudence: On the one hand, the reforms view qiwämah as a shared responsibility between spouses, but on the other they maintain the historic juristic pairing of the wife's obedience in exchange for the husband's maintenance. Sharafeldin also shows that attempts at reform are highly influenced by political and socioeconomic factors, as well as the activists' own ideological and religious situatedness. The author's brief discussion on the relationship between knowledge and authority, in terms of interrogating traditional standards of valid Shari'ah interpretations, is a significant contribution to the volume.

In the next chapter, Lena Larsen explores how Muslims deal with the tensions between the lived realities of Muslim women in Western Europe and the idealized notion of marital roles in juristic doctrine. Larsen concludes, from fatwas issued by Syed ad-Darsh and the European Council for Fatwa and Research (ECFR), that muftis maintain the prevailing juristic gender-complementarity and hierarchy model despite acknowledging the 
changing realities that challenge it and their failure to provide any substantive solutions to the new problems that juristic ideals pose for the contemporary Muslim family.

Co-written by Mulki Al-Sharmani and Jana Rumminger, "Understanding Qiwämah and Wilāyah through Life Stories" continues the practical considerations of these concepts and shows how men's juristic rights affect women. The author's aims to collect women's stories included producing knowledge that would facilitate social and political reforms in the participating countries. Many of the collected stories illustrate that male guardianship over women rarely functions as a system of security and protection for young women; rather, it becomes a tool of exploitation and marginalization. The women's experiences with challenging and often oppressive gender relations in their marriages become a source of knowledge for them about Islam, or at least a motivating force to question the established norms and their pertinence to and impact on their lives.

The last chapter, "The Ethics of Tawhìd over the Ethics of Qiwāmah," presents a moving account by Amina Wadud in which she exposes various failures of the idea of qiwāmah in fiqh. She first ponders the impact of slavery on African-American family structures that dominant juristic discourses neither represent nor acknowledge. She then argues that that the notion of qiwāmah contradicts tawhīd because it requires unequal relations among humans. Her proposed tawhidic paradigm replaces the existing vertical hierarchy of God above man and man above woman with God above both men and women. In this view, women and men are in a direct and vertical relation with God, but in a direct and horizontal relation with each other.

The common themes pursued across the book deserve a mention. Some authors (e.g., Mir-Hosseini and Sharafeldin) explicitly point out that the reforms of family laws in Muslim countries fail to acknowledge the very assumptions of marriage posited by the Muslim legal tradition: that God placed women under male authority and that marriage is a contract of exchange and sale. Abou-Bakr and Lambrabet expose the circular logic that God granted men this authority because they are superior due to their socially privileged status as men. Importantly, also, the discussion of gender privileges a specific set of gender roles and rights, overlooking other important ones. Welchman and Larsen briefly discuss the disregard of traditional inheritance rights, and Sharafeldin addresses the lack of mention of inheritance laws as well as women's right to interfaith marriages in reforms. However, all three chapters could have benefited from a more thorough analysis of these omissions. 
The book maintains a fine balance of the theory and practice of qiwämah and wiläyah. While at times feeling slightly repetitive - for example, many chapters repeat the meanings and origin of qiwämah - it promises to be an important part of the canon on Islamic feminist scholarship. The message of a clear contradiction between the Qur'an and its interpretations cannot be highlighted enough. Men in Charge? is a continuation of the Islamic feminist struggle to convey this message, to show the contradictions within the Islamic tradition itself, and, in fact, to deconstruct the mere idea of an "Islamic tradition" and question its authority.

Shehnaz Haqqani

Doctoral Candidate, Islamic Studies University of Texas at Austin, Austin, TX 